\title{
Online Shopping Behaviour among International Students from Belt \& Road Countries in China
}

\author{
Md Shohidul Islam
}

\section{ABSTRACT}

The rapid transformation of e-platforms and the growth of e-commerce in China provide consumers with the most advanced channels and creative options for buying and selling through online podium. Online shopping is categorically going to be the world's future shopping mode. Besides, The Belt and Road Initiative (BRI) of China aims to place the world on a new trajectory of higher growth and human development through the connectivity of infrastructure, increased trade, and investment. Crossborder online shopping has become one of the forthcoming prime business models through the implication of the Belt \& Road Initiative. By analyzing the representative group of consumers from Belt \& Road countries, this study is to explore possible guiding constraints about online shopping decisions that may assist to understand behavioral traits to cross-border online shopping. In the expansion of online shopping, consumers, particularly young people, and students play the most important role. It is, therefore, imperative for companies to investigate and consider the factors that affect the decision of students and young people to get online shopping. This paper has attempted to explore various factors that will affect the online shopping decision of consumers particularly from Belt \& Road countries. During this analysis, a qualitative study approach was adopted and a sample of 105 higher education students from the Belt \& Road Initiative (BRI) countries studying at Capital Normal University was drawn up. The study will ascertain the 'Online Shopping Behaviors' of typical consumers from BRI (Belt \& Road) countries to explore a wider direction for cross-border online shopping decisions. It is discovered that online shopping makes life easier, and it is not so far that online shopping can infinitely overtake conventional physical shopping in the whole world.

Keywords: Online shopping decision, E-commerce, Consumer behavior, Promotion strategies, Belt and Road Initiative, Influencing factors of online shopping, BRI, CNU.

\section{INTRODUCTION}

The evolution of Internet technology has brought tremendous changes in global business. The internet has created a new environment of E-business, E-Commerce, and E-transaction. It has provided opportunities to attach buyers through the online network worldwide. The usage of the internet has increased because of its significant tools of fast information delivery to the users, also providing more choices of searching in the shortest possible time. Within the same way, the Internet has transformed the way of business by allowing retailers to offer an unlimited range of products and services to all consumers around the world at any point at any time. At the current, E-business, ECommerce, Online Shopping are substituting traditional business forms radically. Online shopping opens a new window for the business where an individual is benefited from using internet technology to shop for and sell products electronically. Today, online shopping is becoming more and more popular and essential to everyone. Now, people first think about online shopping once they want to shop for something. Online shopping enables consumers to shop for products $24 \times 7$ basis from whole around the world. The easy answer for busy lives in today's world is online shopping.

Though, various influencing factors of consumer behavior heavily impact online shopping mode. Online shopping required more customer intentions compare to buying physically. Although the rapid growth of the online shopping market is optimistic for future growth, negative aspects arose in some respects also. There are various influencing factors such as trust, availability of information, delivery time, security, etc. are the keys to buy decisions from online. China's Belt and Road Initiative (BRI) and tremendous advancement in E-Commerce are the foremost significant economic concepts that are going to change the world's business manner. As a part of the Belt and Road implication, China has scoped golden opportunities to attract overseas talents from Belt and Road (BRI) countries. Students from BRI countries are being introduced directly to the e-phenomenon of China in every aspect of their everyday life.

This research study is to focus on behavioral traits to online shopping, and also the impacting factors or barriers to online shopping upon students from Belt and Road 
(B\&R) countries studying in Capital Normal University, Beijing, China. This study is also to direct to comprehend the qualities of cross-border online shopping.

\section{LITERATURE REVIEW}

\section{A. Online Shopping Behaviour}

As a new form of e-business, assessing the online shopping behavior of consumers has been an extensive curiosity of the researchers in the current e-era. Especially next epoch of COVID-19 online has been becoming the vital means to daily shopping. E-commerce and Online shopping are the fieriest topics to the researchers for their significant potentials.

The significance of attitudes toward online shopping established the relationship between the attitude to online shopping with shopping orientations and perceived scales of benefits; and analyzed factors that affect the attitudes of students towards online shopping. The results indicate that utilitarian orientations, convenience, price, and wider selection are important determinants of consumer's attitudes toward online shopping [9].

Offline and Online consumer behavior processes identified some basic factors that drive the consumer to decide to buy or not to buy through an online channel. It identified online shopping has the complete features of buying such as searching products, price evaluation and comparison, quality assessment, choosing the service type, and processing the payment system [24].

It was analyzed the factors affecting the consumer's attitude of trust and their impacts on internet purchasing behavior that revealed online shopping behavior traits [1], [25].

Deliberated the influences of online shopping information dependency and innovation on internet shopping adoption [14]. The influence of the trust perspective on the intention to buy online was specifically investigated focused on consumer characteristics such as age, gender, and income [22], [17].

By investigating demographics and value orientations for online shopping, the structural equation modeling analysis was employed. It was found that openness to change orientation and 'self-enhancement orientation' had a direct or indirect positive effect on the online shopping behavior of respondents, whereas 'conservation orientation' and 'selftranscendence orientation' were not important in the estimation of the equation [35].

A store brand-customer behavior was studied in France, China, and Malaysia to investigate the factors influencing consumers' online. It showed that consumers' choice variations significantly depend on demographic factors [11], [16].

Consumers adoption of online shopping and hypothesized relationships such as deciding factors in Ecommerce, Website factors, Perceived Risk of Consumers has experimented. It observed the lifestyle characteristics of online consumers and explain that consumers often choose to shop online because they like having products delivered at home and want their purchases to be private [6].
Online shopping among college students has brought out gender differences in online shopping. The study revealed college-going youth's tendency to shop online and what methods they prefer for shopping. It also showed more and more youths are gaining confidence about purchasing products in online [33].

Through evaluating the Chinese E-commerce market, and developing an E-commerce business model, it specified whether 'brick and click' would be an ideal strategy for Ecommerce companies to promote their brand awareness and customer satisfaction. Moreover, it explored the largest competitors in the E-commerce industry and developed a SWOT assessment [36].

Based on the social cognitive theory a research model of online shopping behavior is proposed that argues trust has a positive impact on online shopping behavior, and online shopping behavior is negatively and directly affected by perceived website complexity. It is explored the relationship between perceived website complication and online shopping behavior that points out the online store environment as a key factor in online purchase [5].

\section{B. International Students; Belt and Road Initiative (BRI)}

China's One Belt, One Road Initiative is a new development model and modernization strategy to promote 'peace and cooperation, openness, and inclusiveness, mutual learning, and benefits.

As of March 2020, 138 countries have been joined the Belt and Road Initiative (BRI). The countries of the Belt and Road Initiative (BRI) are spread across all continents: Particularly,

38 countries are in Sub-Saharan Africa

34 BRI countries are in Europe \& Central Asia

25 BRI countries are in East Asia \& pacific

17 BRI countries in Middle East \& North Africa

18 BRI countries are in Latin America \& Caribbean

6 countries are in South East Asia [34].

Belt and Road Initiative (BRI) is not only promoting business and infrastructure development but also sponsoring talent exchange programs. China has opened its doors for foreign students and researchers through BRI getaways. China is attracting a record number of foreign students from BRI countries every year. Now learners from BRI countries get a special opportunity to introduce new China's development in information, technology, and business sectors.

The BRI has encouraged Chinese higher education institutions to build partnerships with international universities. The Belt and Road Initiative is dedicated to 'boosting the local economies, growing local jobs, enhancing local livelihoods' of participating nations. Education can play a pivotal role in achieving this by empowering local groups and providing a means for inclusive development [12].

Belt \& Road Initiative (BRI) emphasizes not only 'social and cultural exchanges' but also highlights the 'knowledge economy' to future-oriented digital infrastructure and interconnectivity. BRI is a new phase of globalization that builds connectivity with Eurasia and can reconfigure global higher education partnerships with universities in 130 countries, as well as new partnerships with Russia and the 
EU. Foreign students along the belt and the roads are competing to enroll in Chinese universities in this new environment. Belt and Road spaced Chinese scholarships to the students from nations along the route and reshaping regional education and moving global higher education. In the past year alone, Belt and Road partner countries' enrollment has jumped 12 percent to 317,000 students. Chinese universities become 'magnet institutions' for students from BRI developing countries. Belt and Roads Initiative provides an opportunity for the basis for the philosophy of the Chinese vision of BRI 'peace and development' and a 'future for humanity' [29].

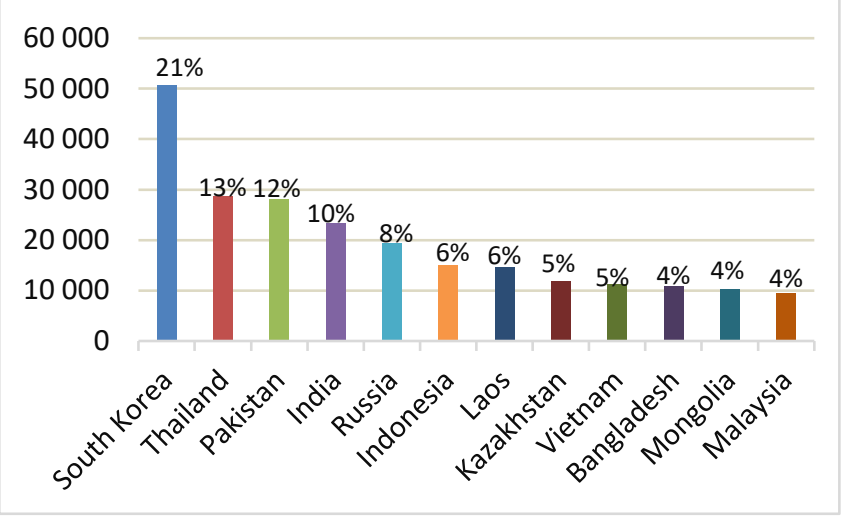

Fig. 1. The top 15 countries sending students to China in 2018. Source: Ministry of Education of the People's Republic of China. [online] Moe.gov.cn.

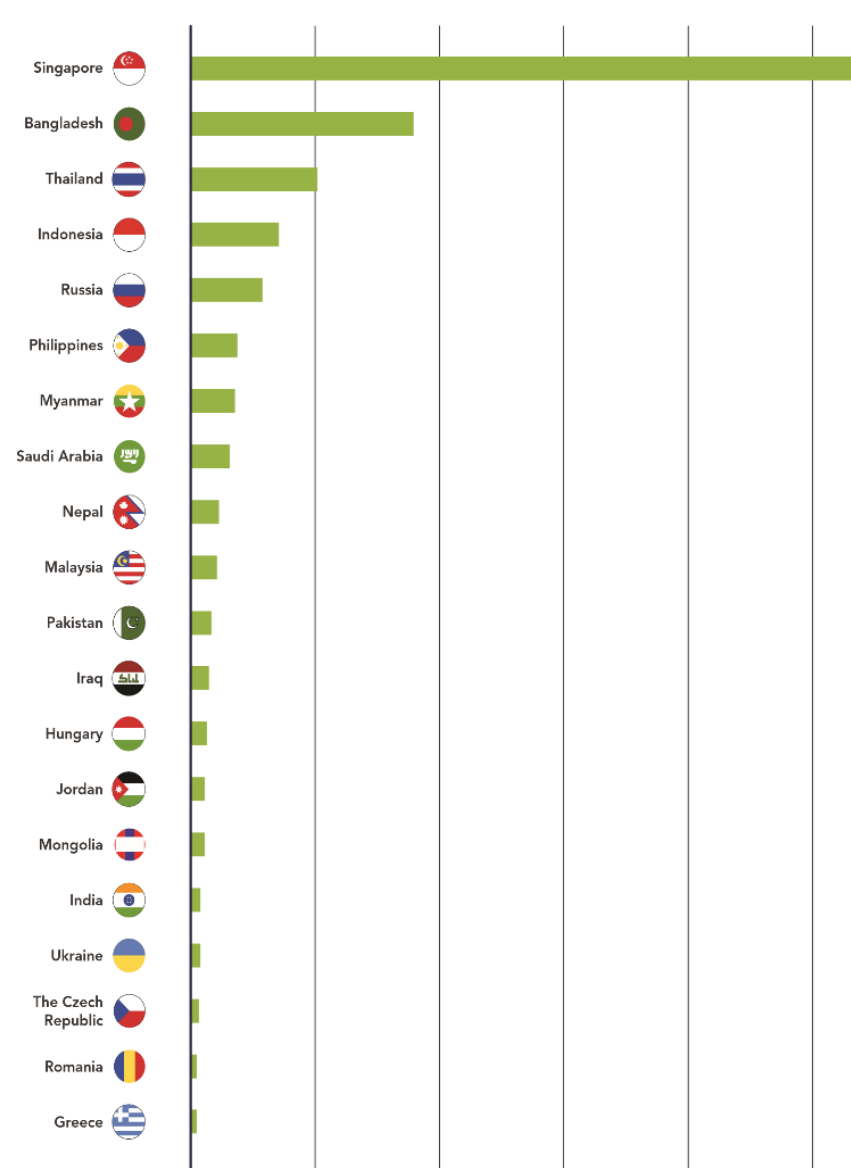

Fig. 2. Top 20 Destinations of Chinese immigrants in Belt and Road Countries (thousands).

Source: CCG Blue Book of International Schools 2017.

\section{RESEARCH PROBLEM}

There are several studies and essays on online shopping and most of them have discussed market patterns, attitudes, motivation, and obstacles when shopping online. Some aspects of previous surveys explored the concern of individuals regarding online security, which item they choose to purchase online, the devices, payment, and delivery methods they prefer, whether they shop online or not, and the effect of online shopping on conventional stores. While a lot of research has been carried out in most countries, there have been very few studies that concentrate on only certain groups of individuals and examine their online shopping characteristics. Therefore, this study focuses on University student groups from Belt and Road countries, studying in China and analyzes their shopping behaviors, their motivation and barriers to online shopping, and the influences of online shopping on their shopping habits.

\section{RESEARCH OBJECTIVES}

The key objectives of the study are to:

(1) To know the online shopping behaviors of students from BRI countries in Capital Normal University.

(2) To identify students' preferences towards different E-shopping platforms.

(3) To investigate the extent of attitudes of students towards online shopping.

(4) Determine influencing factors to the online purchase decision.

\section{RESEARCH METHODOLOGY}

\section{A. Research Design}

This study used descriptive research. Descriptive research involves gathering data that describe events and then organizes, tabulates, depicts, and describes the data collection [15]. It often uses visual aids such as graphs and charts to aid in understanding the data distribution. Therefore, it offers a better clarification on online shopping, and ultimately give a clear picture of the effectiveness and reliability of online shopping and its relationship to purchasing decision.

\section{B. Questionnaire Development and Measurement}

To measure the online shopping behaviors of university students from BRI (Belt \& Road) countries, a specific questionnaire was developed. The questionnaire was divided into two parts (Part A \& B).

Part A- was intended to identify the Students'(consumers) attitudes to analyze their behavior, motivations, and barriers including the kind of products or services they often buy, and websites, devices, and payments they prefer to use as well as the advantages, disadvantages, influences of online shopping on their shopping habits. Part-A included twenty-seven questions, which were separated into twelve categories in terms of the independent variables and dependent variable. Multiplechoice questions, ranking questions, open-ended questions, and questions where more than one choice can be checked 
were used. Using a five-point Likert Scale measurement that ranged from $1=$ strongly disagree, $2=$ disagree, $3=$ indifferent (neutral), $4=$ agree, and 5= strongly agree, the respondents were asked to provide their rating on their experience.

Part B- was proposed to collect the respondents' demographic information such as gender, age, level of education, language proficiency, and monthly spending level of the respondents. A total of eleven questions were included in this part.

\section{Sources of Data}

Primary and Secondary methods are used for collecting data. Online Survey is used for collecting primary data by a structured questionnaire.

\section{Population of the Study}

Capital Normal University (首都师范大学) has 11,245 undergraduates, 6,691 masters, 851 Ph.D. students, and 2,155 international students, 1,200 students from BRI (Belt \& Road Initiative) countries as of November 2020 according to the varsity website and official sources [18]. This study targeted international students from Belt and Road countries from all groups studying at Capital Normal University, China because of their background diversity and exposure to online shopping. Students of the Capital Normal University are provided a hundred percent with Internet access through wireless connection, and therefore, the chances for them accessing online shopping are very high. On the same basis of their diverse background, only students from the International campus were chosen for this study.

\section{E. Sample Size}

Respondents were randomly selected to come up with a representative sample of the entire population. Total numbers of the sample were able to collect one hundred and five (105). The respondents are both male and female.

\section{F. Data Collection Procedures}

The structured questionnaire was prepared in both word document format and online format to get a larger sample and more diverse participants. The online questionnaires were distributed in WeChat \& E-mail. Microsoft Forms, an online survey tool was used to upload the questionnaire to the Internet and transform it into the online format. This survey was also sent to university student groups in WeChat to get more participants.

\section{G. Tools and Techniques of Data Analysis}

The study applied both nominal and ordinal scales to measure a range of factors establishing the effectiveness of online shopping behavior and interval scale in determining the relationship between online shopping and consumer behavior. The analysis of the data was done using descriptive and inferential statistics. Percentage analysis was carried out to show the results. Microsoft forms, Microsoft Excel tools were used for analyzing data. Relationships between responses were assessed and presented using Pie Chart, Line chart, Table, etc.

\section{DATA ANALYSis, Results, AND Discussion}

As per analysis and findings, the results are presented on the effectiveness of Online Shopping Behavior Among Students from Belt \& Road Countries in Capital Normal University. The response rate was sufficient and representative. The survey covers the demographic information, and the findings based on the objectives. The findings were then presented in tables, graphs, and charts as appropriate with the explanation being given in prose thereafter. The total respondents are one hundred and five (105).

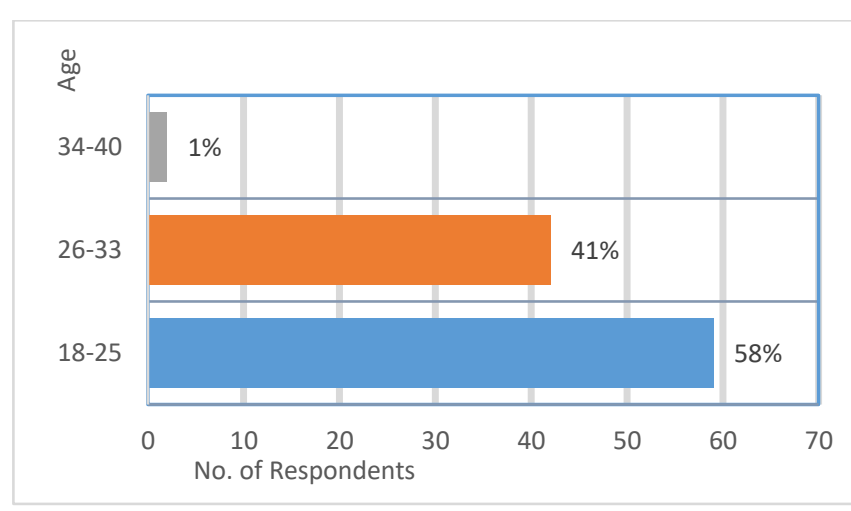

Fig. 3. Distribution of the respondents by age bracket.

This chart shows that most of the respondents are young generation. The total responses are 105. There is no respondent below the age of 18 . Respondent students whose age under $18-25$ years is $58 \%$, under $26-33$ years is $41 \%$ and under $34-40$ years is $1 \%$.

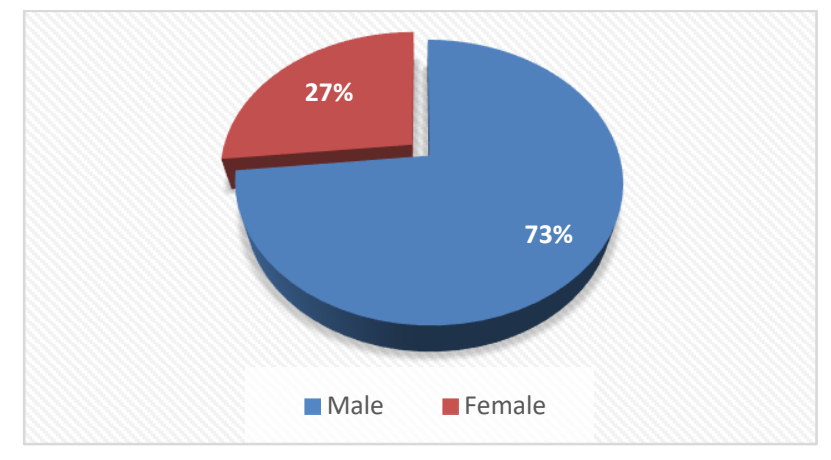

Fig. 4. Gender distribution of the respondents.

The study recorded a higher response rate from male students than female students. Thus, the male has more positive attitudes to online shopping.

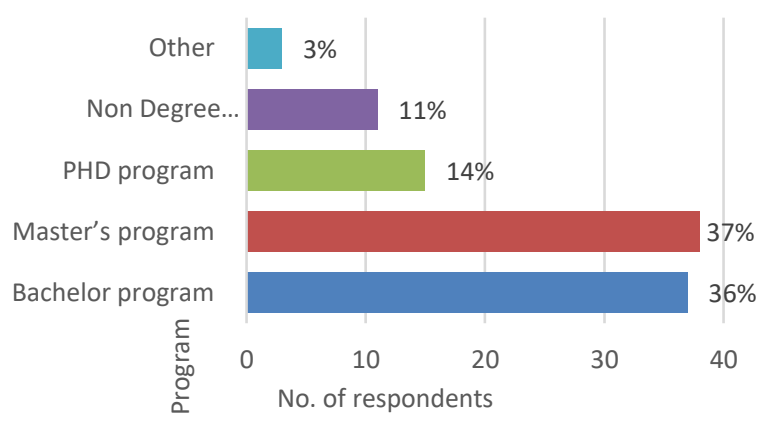

Fig. 5. Distribution of the respondents by the program of study. 
This chart shows that $37 \%$ of students from BRI countries are studying in the Master program, 36\% in Bachelor Program, and 14\% in Ph.D.

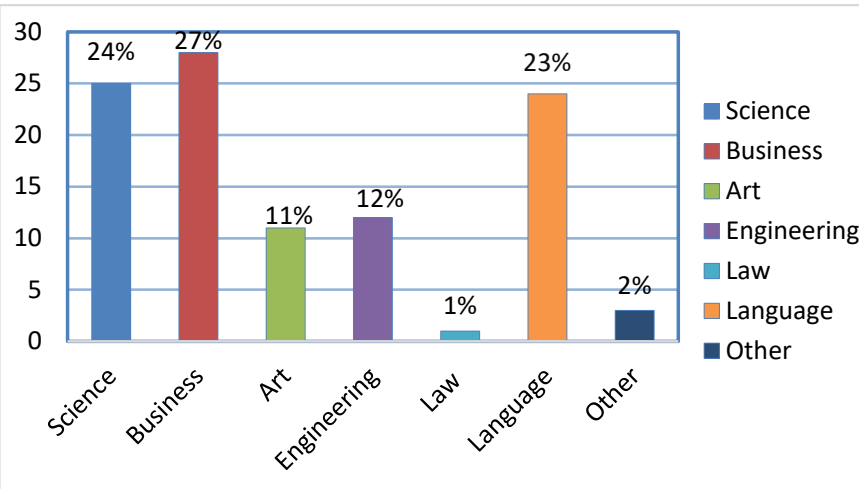

Fig. 6. Distribution of the respondents by major subject?

This finding indicates respondent students of Capital Normal University are the majority of Business Group.

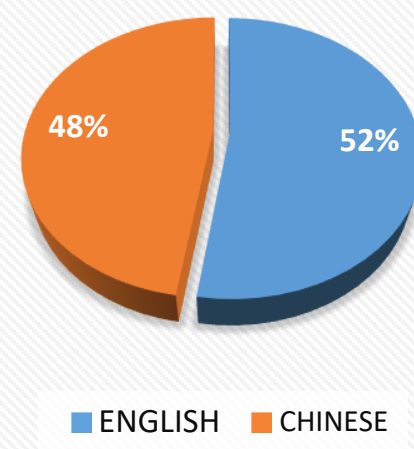

Fig. 7. Program's medium of Instruction.

That is, $52 \%$ of respondents' students' medium of instruction is English and $48 \%$ is Chinese.

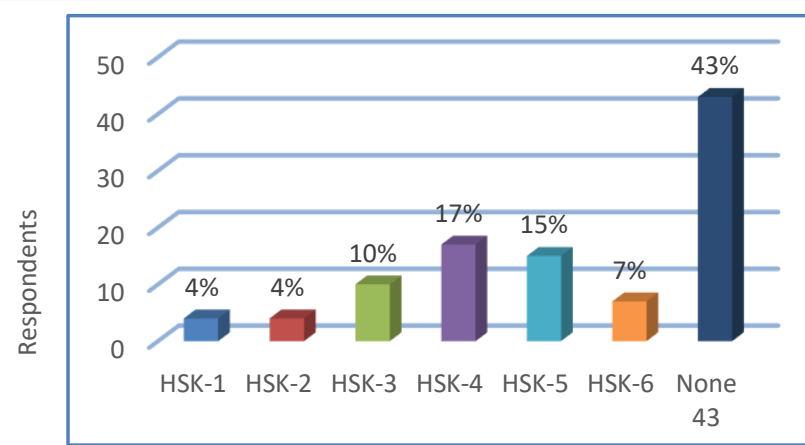

HSK Level

Fig. 8. Your Chinese Language Skill Level?

This study indicates more than $50 \%$ know the Chinese language, whereas $43 \%$ have no Chinese language skills at all.

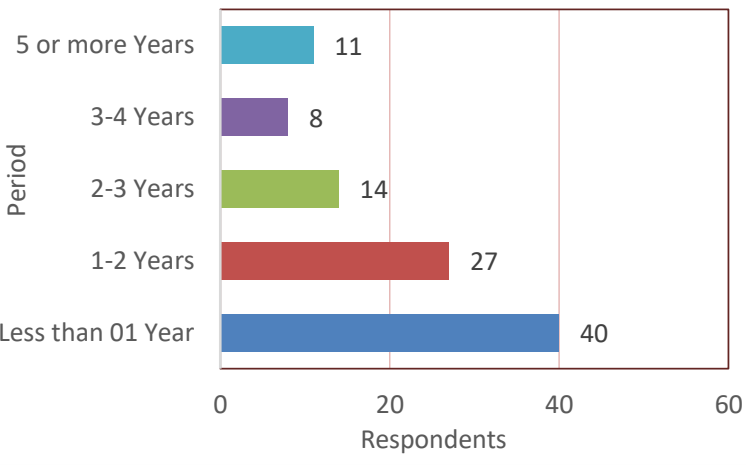

Fig. 9. The number of years has been studying in China.

This study shows that the maximum number of respondents are studying at Capital Normal University for less than 01 year.

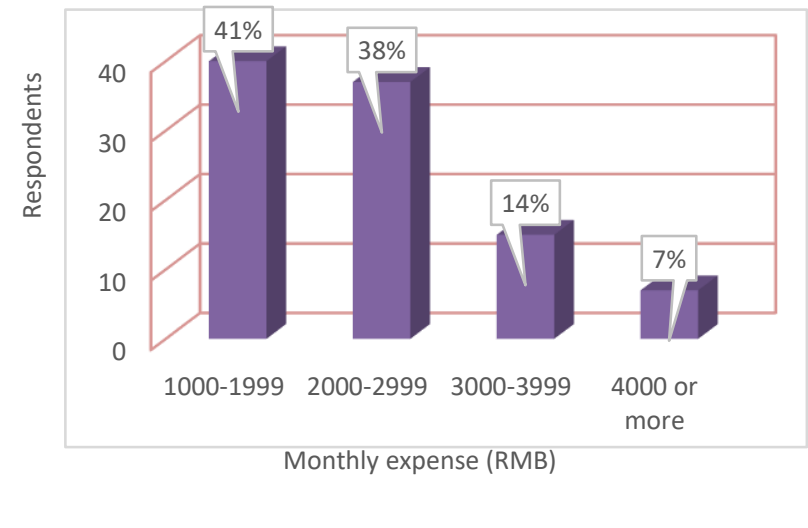

Fig. 10. Living and spending fee per month in RMB.

This figure indicates the majority of students spend 1000$2000 \mathrm{RMB} /$ per month to carry out necessities.

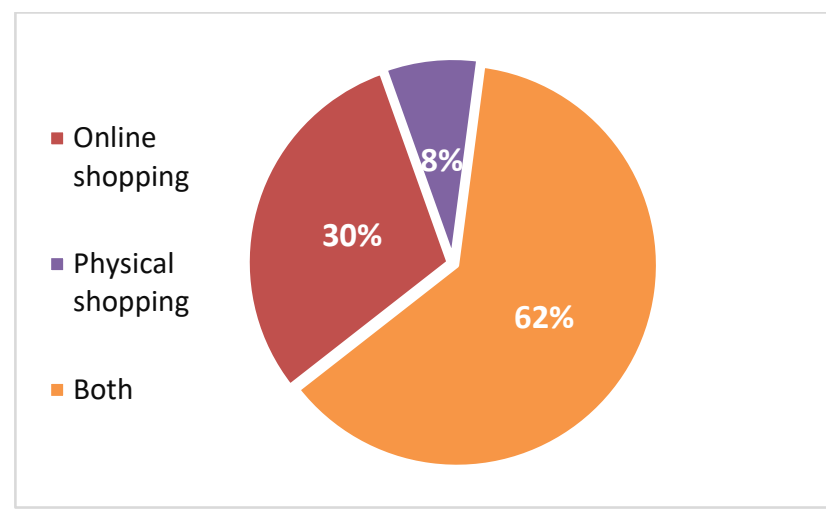

Fig. 11. Which shopping method is comfortable for you?

This chart shows that maximum students prefer online shopping to physical shopping. 


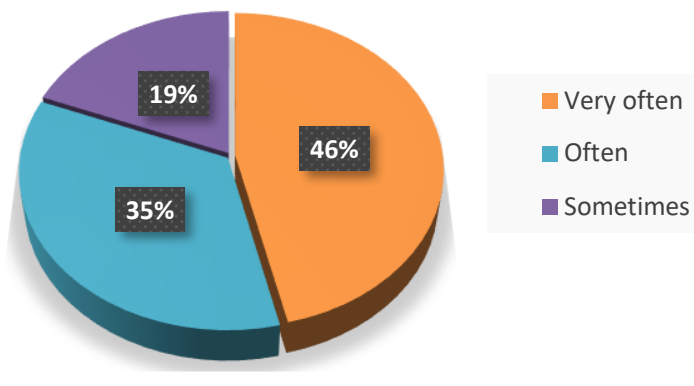

Fig. 12. How often do you use the Internet for shopping?

This chart indicates that students do online purchase frequently.

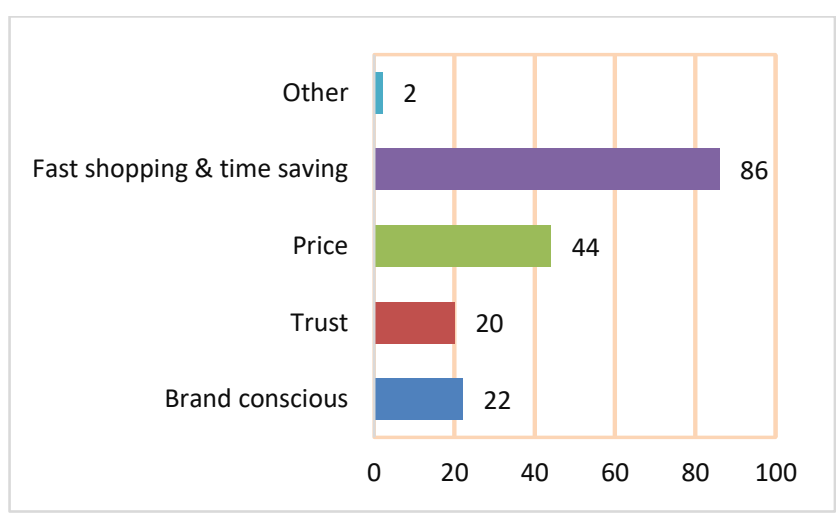

Fig. 13. Why you prefer online shopping?

This survey shows that consumers prefer online shopping because of mainly first shopping and time-saving features.

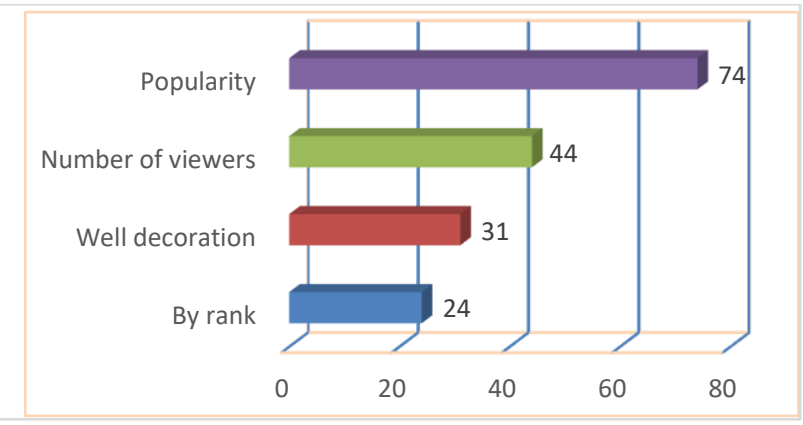

Fig. 14. How do you judge web sites for shopping?

The majority of respondents select online platform by their popularity, then the number of viewers.

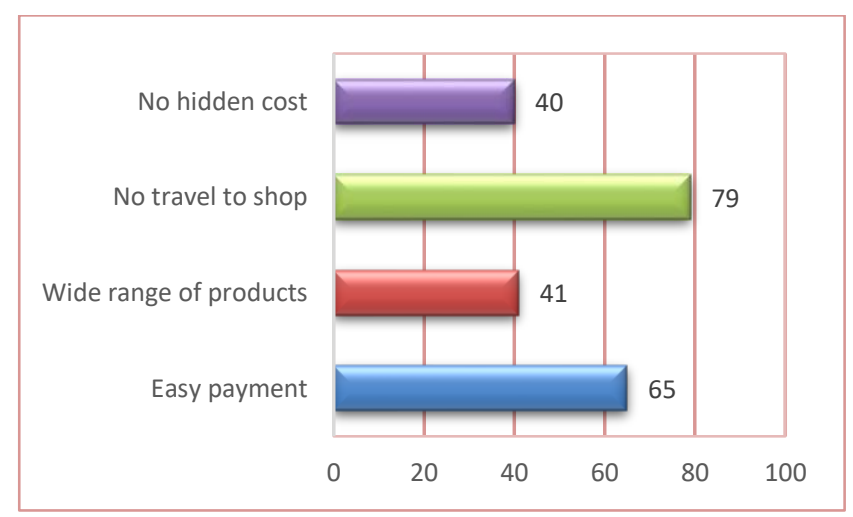

Fig. 15. Which motivational factor do you prefer to do online shopping?
It shows that 'No travel to the shop' and 'Easy transaction' are the most influencing factors behind online shopping.

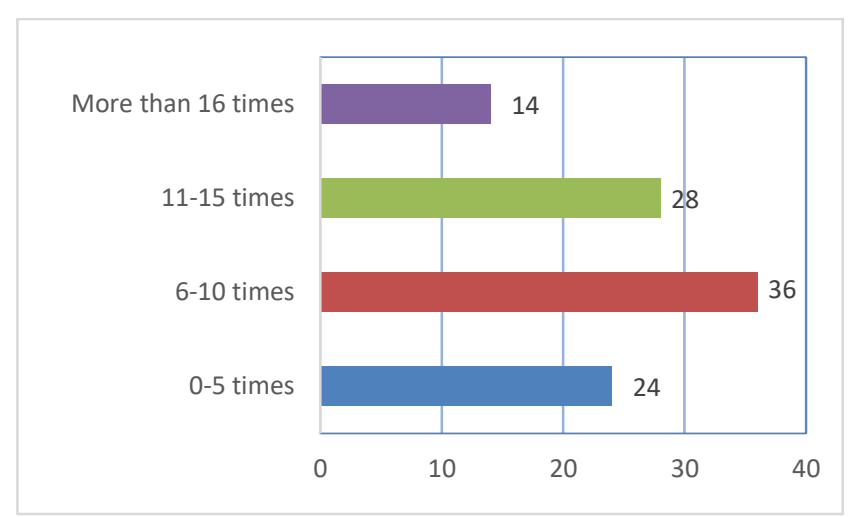

Fig. 16. How many times do you have online shopping monthly?

This indicates, the majority of respondent students buy at least 06 times and more from online in a month.

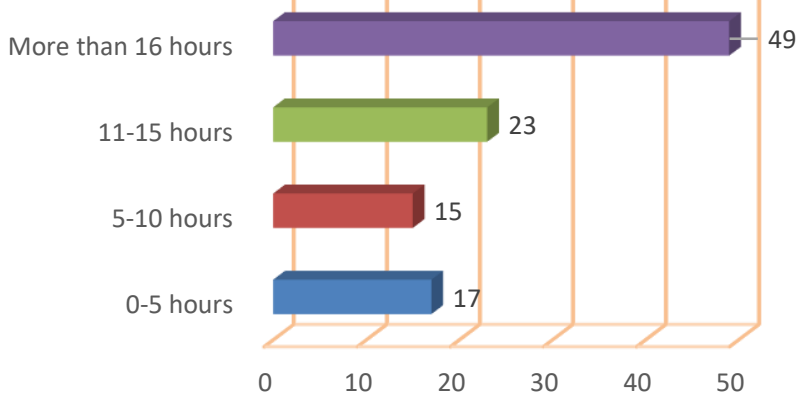

Fig. 17. On average how much time (per week) do you spend surfing the web?

The study recorded that the majority of students spend an average of 16 hours /per week surfing websites.

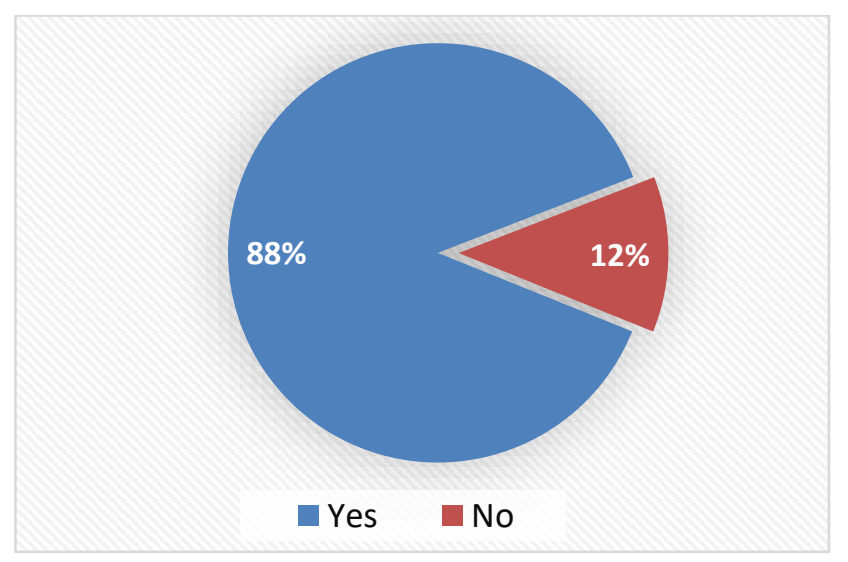

Fig. 18. Do you compare price and product specification before purchase?

It indicates, the majority of shoppers compare price and product features before the final order to purchase from different online shops. 
European Journal of Business and Management Research www.ejbmr.org

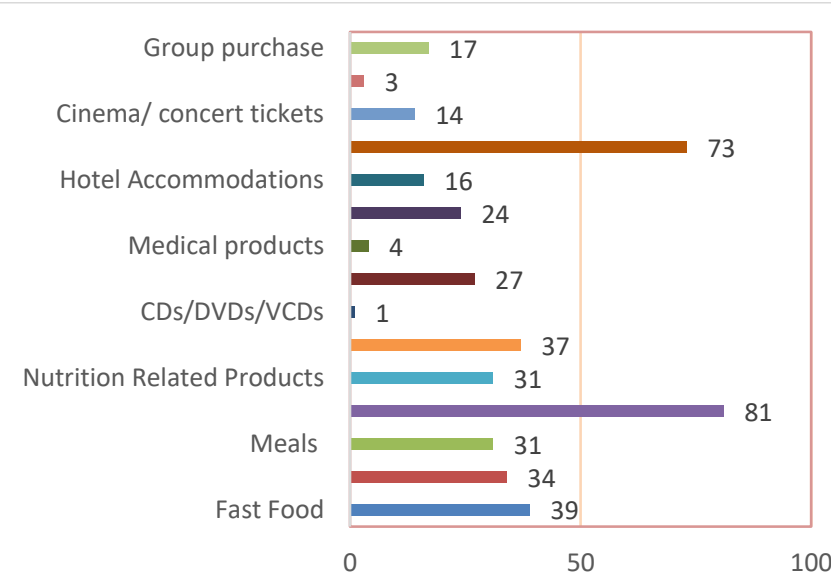

Fig. 19. What kinds of products or services do you often buy online?

This chart shows that the majority of students buy electronics, cosmetics, clothes, and food items from online shopping. Even more, they order all daily products from online.

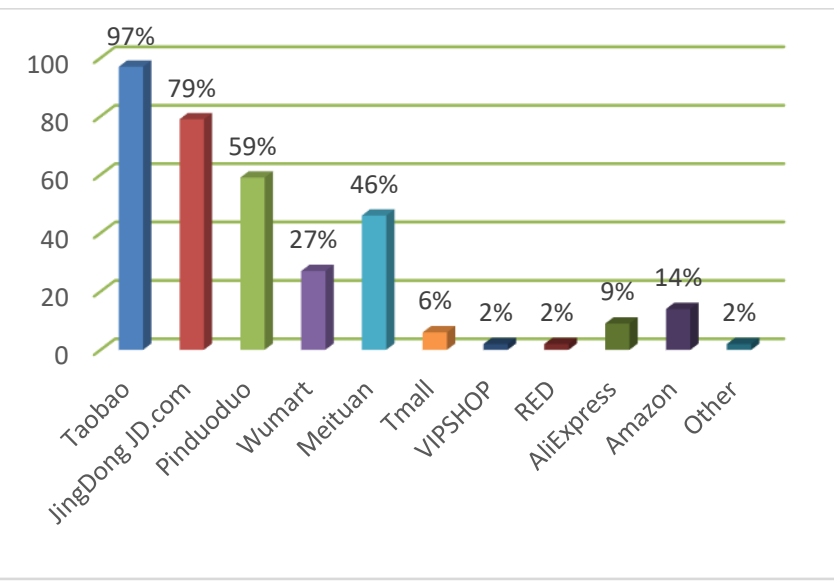

Fig. 20. Which are the websites you use most often when shopping online?

This chart indicates that $97 \%$ of students buy from Taobao, 79\% from Jingdong (JD), 59\% from Pingduoduo. Thus, these 03 are the main market player whereas other platforms like Meituan, Red, etc. are struggling.

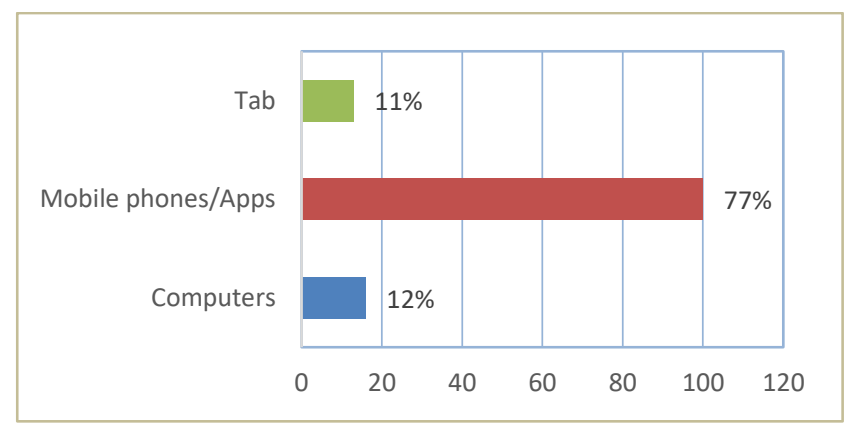

Fig. 21. Which device do you prefer when shop online?

The study shows that the majority of respondents use Mobile Apps (77\%) to buy from online platforms. Thus, online shopping in more percentage is dependent on mobile apps.

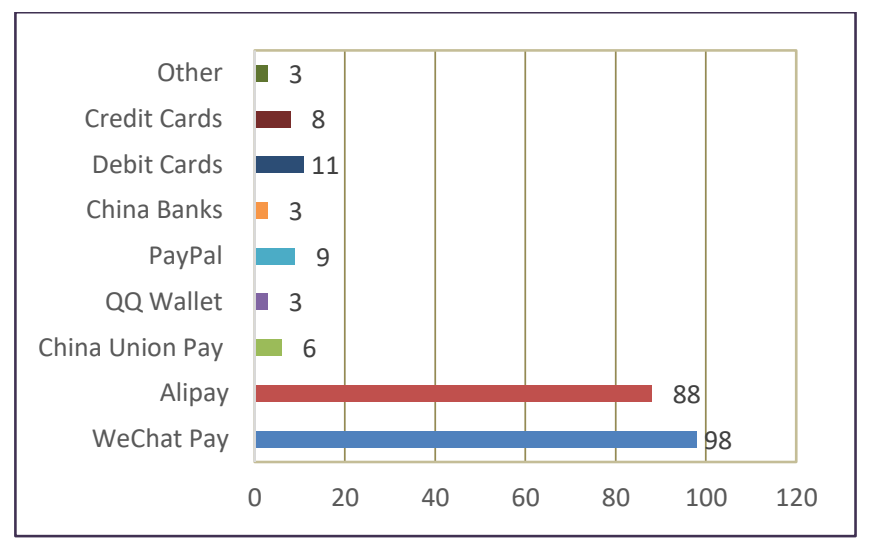

Fig. 22. What are the payments tools you use most often when shopping online?

The above survey indicates that the majority of the students use mainly WeChat Pay (98\%) and Alipay (88\%) as payment tools to complete the transaction.

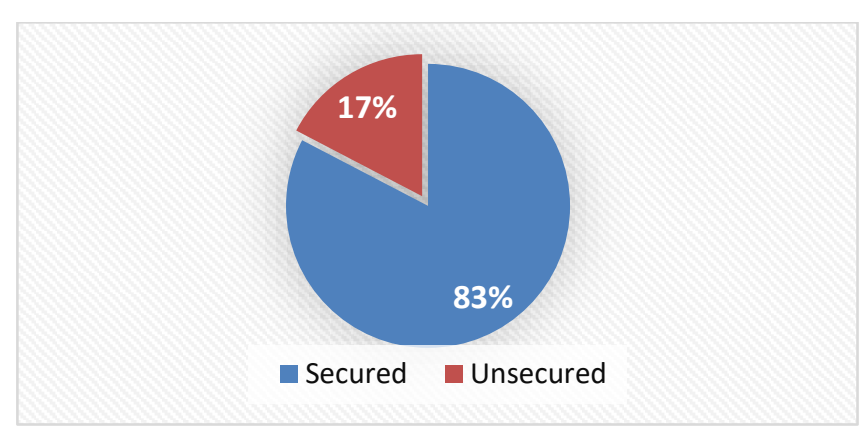

Fig. 23. What do you think, payment on online is?

Thus, $83 \%$ of respondents treat online payment as secured.

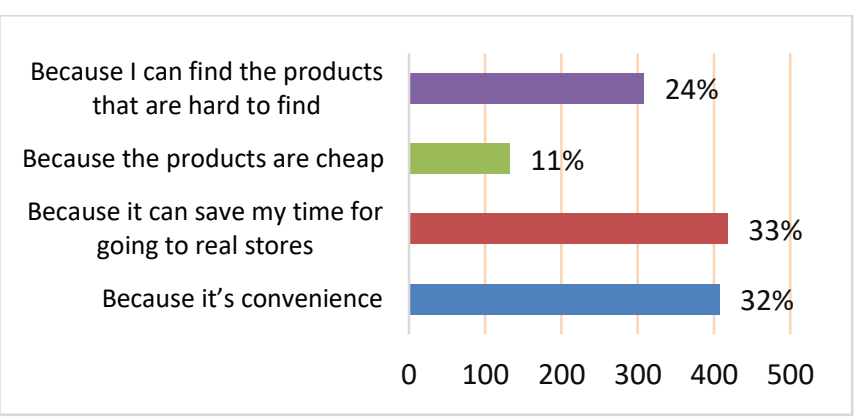

Fig. 24. Please order the importance of following advantages of online shopping by giving score (1-5).

This study shows that majority of respondents like online shopping for its' convenience and time-saving features.

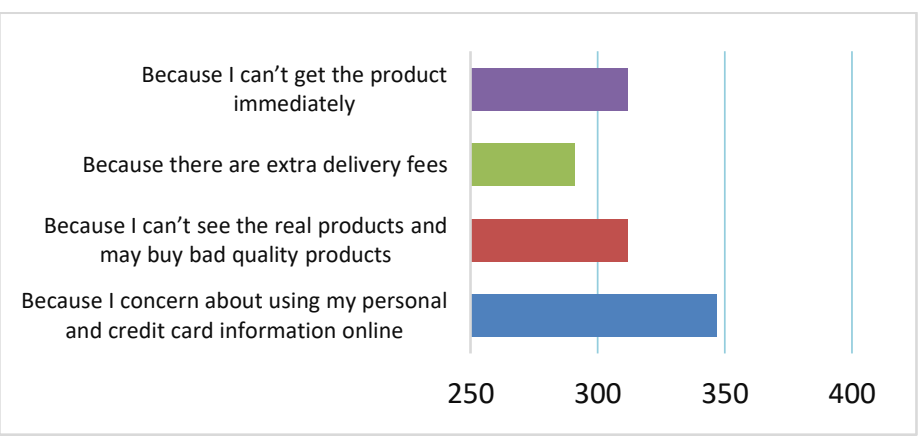

Fig. 25. Please order the importance of following disadvantages of online shopping by giving score (1-5). 
European Journal of Business and Management Research www.ejbmr.org

The study shows consumers are concerns about payment security, extra delivery fee, and late delivery.

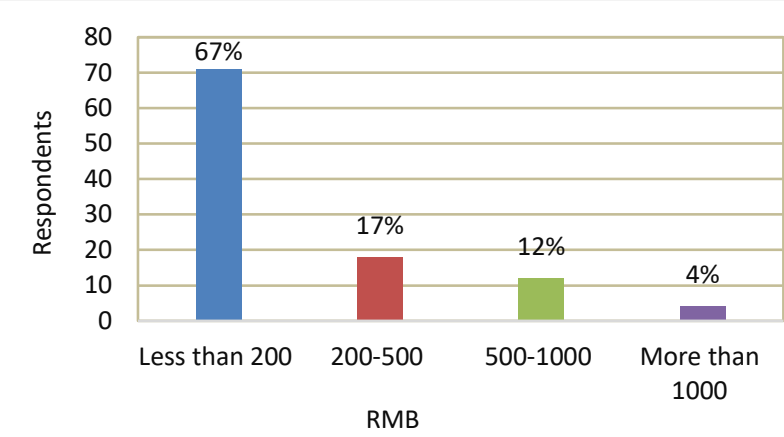

Fig. 26. Select an approximate amount you would spend on a single online purchase (In RMB).

Thus, $67 \%$ of students spend below RMB.200, whereas $17 \%$ order below RMB.500 and $12 \%$ above RMB.500 in a single order.

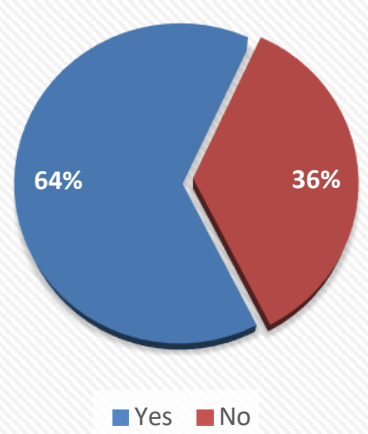

Fig. 27. Do you evaluate the merchant (e-retailer) for purchasing products on websites?

The Study recorded the majority, in number- more than $64 \%$ of respondents consider previous purchase experience to buy from online.

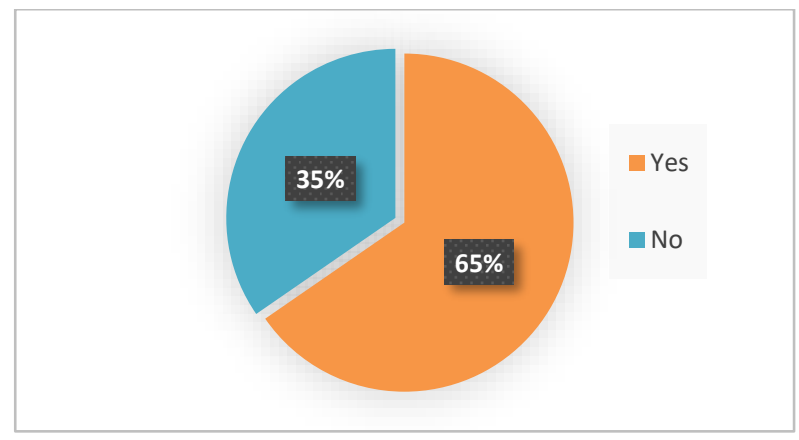

Fig. 28. Do you return the product after purchase?

This chart shows, two-third of consumers return the product after purchase. From 105 respondents: 65\% return and $35 \%$ don't return after receiving products.

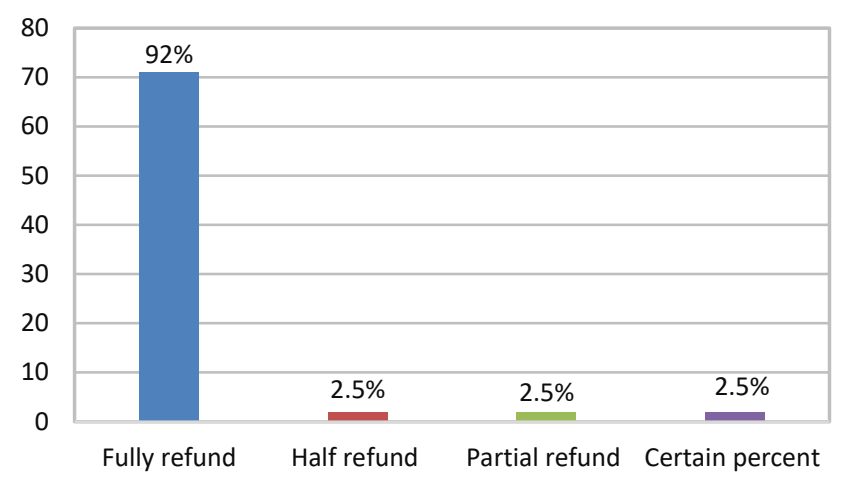

Fig.29. If 'Yes' what about refund.

Thus, $92 \%$ of respondents get a full refund after returning products, whereas $2.5 \%$ get half and partial returns.

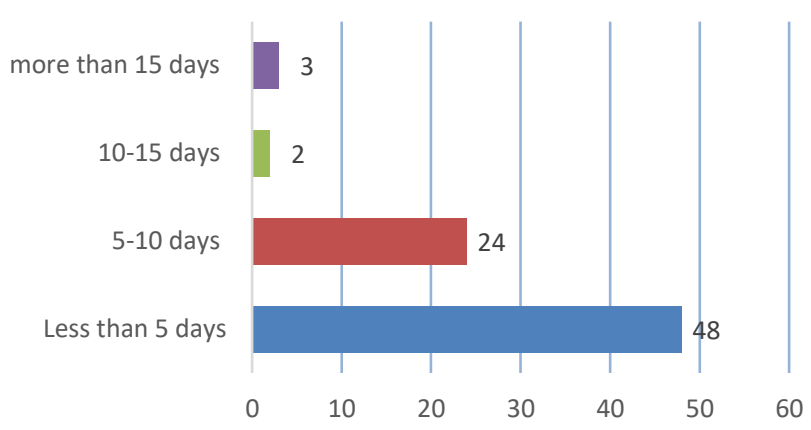

Fig. 30. If yes, how much time they take to refund.

This chart shows how much time an e-retailer takes to refund. $62 \%$ of respondents got a refund within 05 days, whereas $32 \%$ got it by 5 -10days.

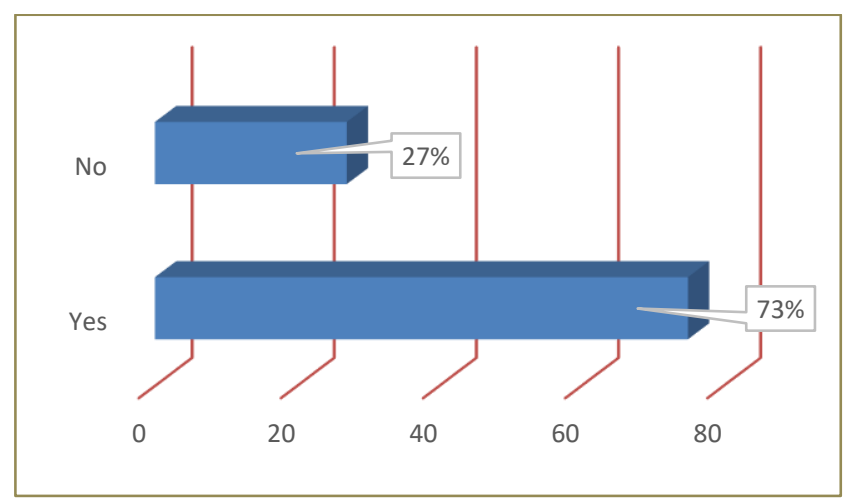

Fig. 31. Have you felt any problems while conducting online purchase?

That is, the majority, $73 \%$ of respondents from total have faced problems while purchasing through online.

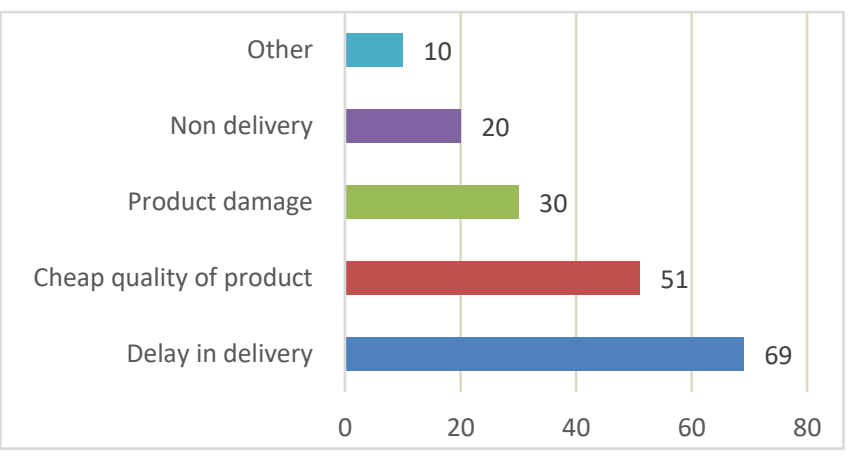

Fig. 32. If 'Yes' what kind of problem? (Check all that apply). 
This chart shows, what difficulties are confronted during online shopping. It shows, $39 \%$ has been suffered from delay delivery, $28 \%$ suffered from Cheap quality products, $17 \%$ suffered from product damage, and $10 \%$ suffered from non-delivery of the product.

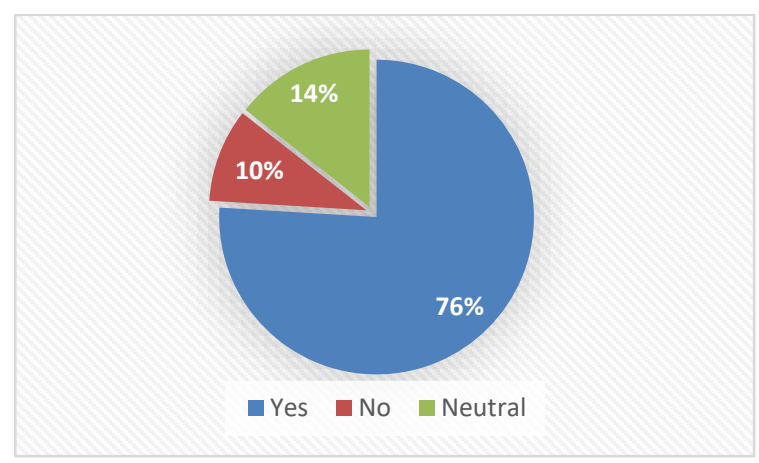

Fig. 33. Are you satisfied in terms of payment, delivery, product, and services during purchase on online?

This chart shows customer perception of payment, delivery, product, and services during purchase. Of 105 respondents, $14 \%$ are neutral, $10 \%$ are negative and $76 \%$ are positive to shop online.

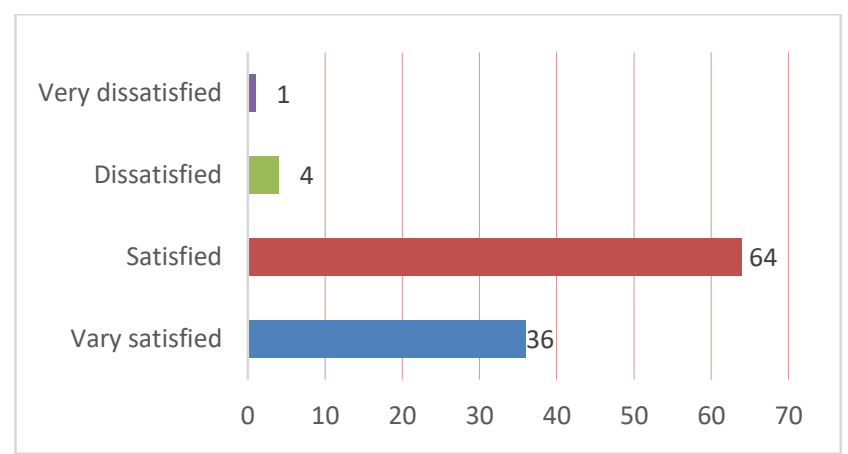

Fig. 34. What is your overall satisfaction/dissatisfaction level after purchasing the product on online?

It shows respondents' satisfaction or dissatisfaction level. $61 \%$ of them are satisfied and $33 \%$ are very satisfied, $4 \%$ are very dissatisfied, $2 \%$ are dissatisfied.

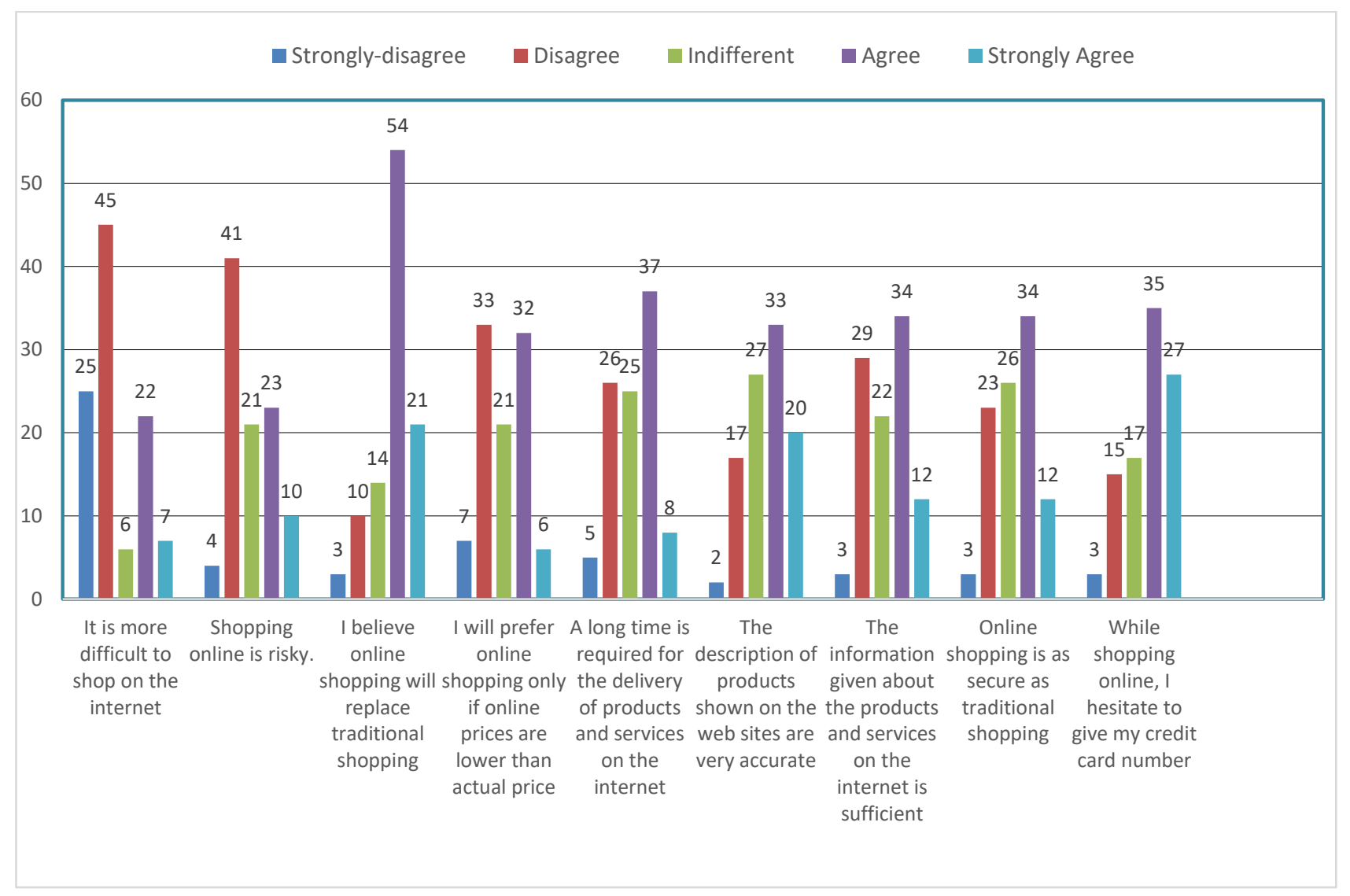

Fig. 35. Please select your level of agreement to the following questions.

This study indicates that the majority of respondents think Online shopping will replace traditional shopping and Online shopping is secure like traditional shopping. On the other hand, they are concerned about insufficient information about products, longer delivery time, the security of payment. 
European Journal of Business and Management Research www.ejbmr.org

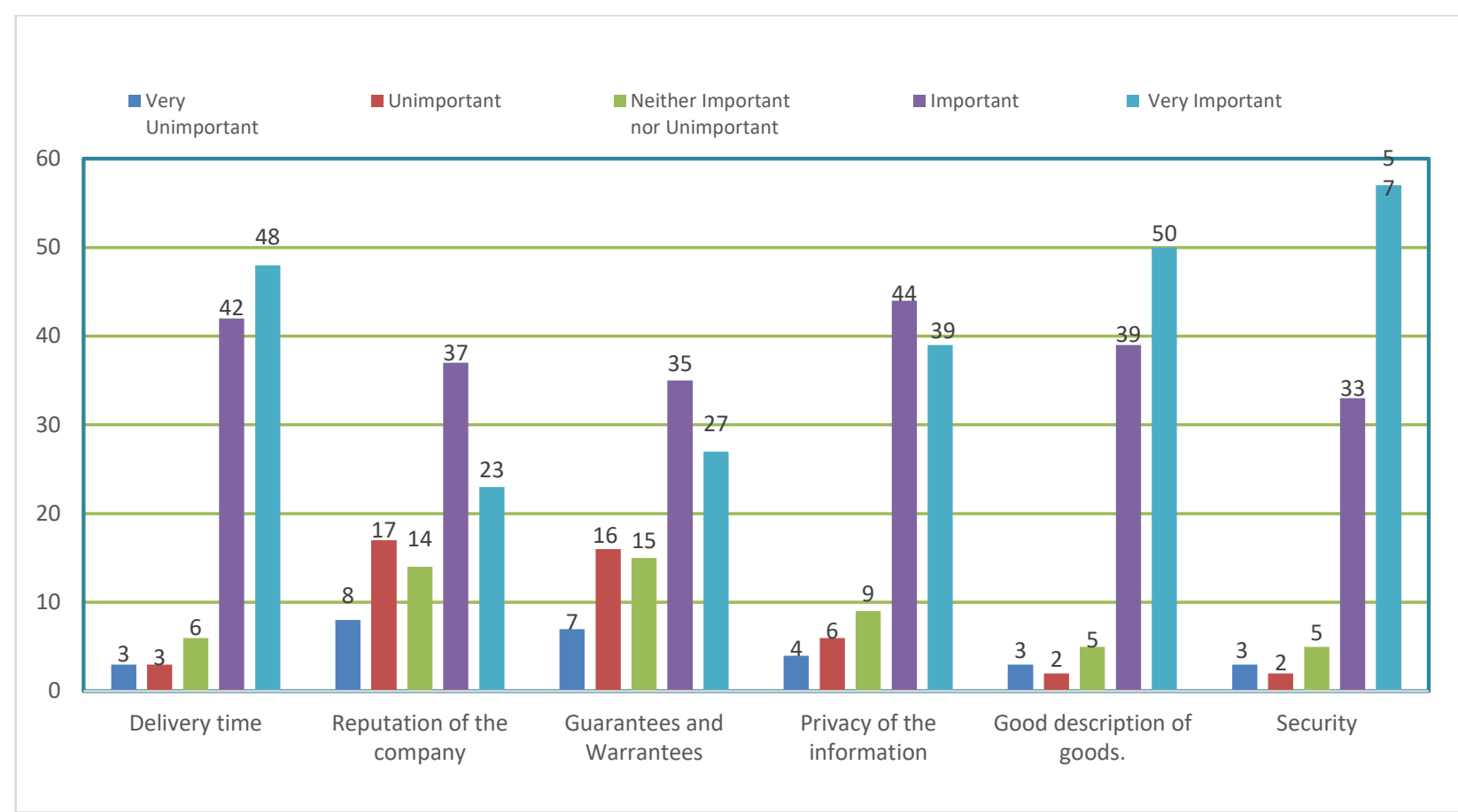

Fig. 36. How important are the following factors in your decision to purchase goods from the internet?

This survey is about purchasing decisions. Delivery time, security, description of goods, and privacy of information are the most important factors to shop online, whereas the reputation of the company, guarantee-warranty are comparatively less significant.

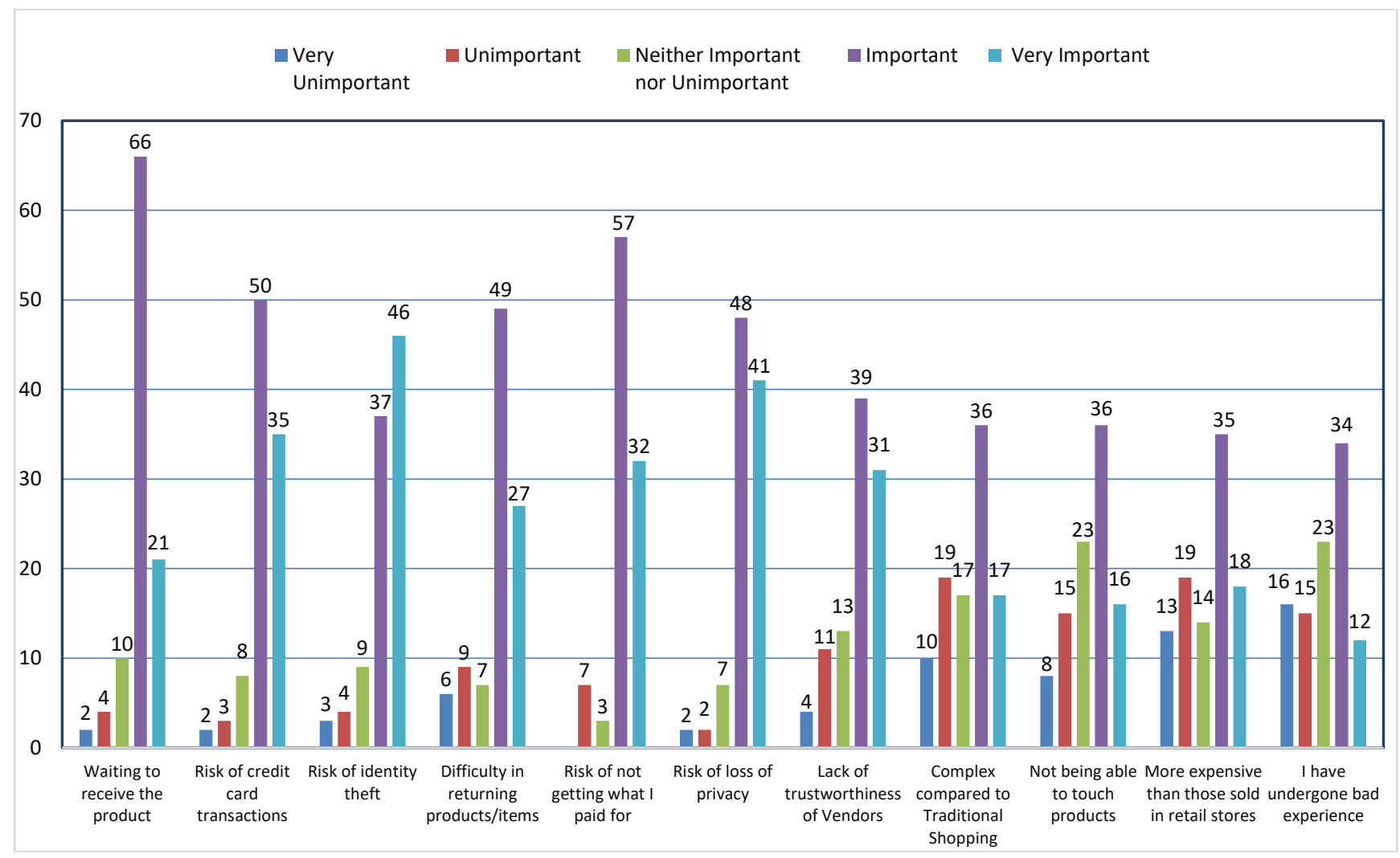

Fig. 37. How important are the following factors in your decision to purchase goods from the internet?

This study shows that the majority of respondents are very much concerned about the risk of not getting products what they actually paid for, risk of identity theft, risk of loss of privacy, the risk to credit card transaction. They are also alarmed about Not being able to touch products, difficulties of returning the products, waiting for receiving the products.
Moreover, respondents are also too price-sensitive to expensive products. 


\section{FINDINGS}

From the analysis of primary data, important information comes to get into the eyes:

(1) Most of the students like online shopping. The average number of students like both online and physical shopping, whereas very few of them like only physical shopping.

(2) Students spend more than 16 hours/ week surfing the internet. It shows students are vastly habituated to the online lifestyle. And they often buy from online.

(3) The students prefer online shopping because of fast shopping and time-saving. A partial number of students are brand conscious, price-sensitive, and believe in trust.

(4) Most of the respondents who conduct online shopping judge E-commerce sites by popularity. A certain number of respondents judges by rank and a low number of respondent judges by web decoration and number of viewers.

(5) Students choose online shopping because of no travel to shop. Some students conduct online shopping because of the availability of a wide range of products, easy payment, and no hidden cost.

(6) Most of the respondents compare products, prices before purchase from different E-commerce sites.

(7) Students are more likely to do online shopping on mobile devices.

(8) There are significant differences in the medium of language among respondents.

(9) Students are mostly like to purchase garments products, electronic products, cosmetics, convenience goods, groceries items, and foods from online shops.

(10) The most popular E-commerce sites are favored by the students - first: Taobao, second: Jingdong (JD), then Pinduoduo, Wumarts, Meituan, Amazon, and AliExpress consecutively.

(11) Most of the respondents prefer WeChat Pay, AliPay as an online payment tool.

(12) Most of them believe that online payment is secured. A low number of respondents do not trust online payment system.

(13) Most of the students spend less than RMB 200 for a single purchase. Monthly average buys from online 06 times and average spend RMB 1000-2000.

(14) Most of the respondents assess e-retailer before purchasing the product.

(15) Majority number of consumers return the product after purchasing from online.

(16) Most consumers get a full refund because of returning the product and very few consumers get half and partial refunds.

(17) Most e-retailer refund amount less than 05(five) days. Some e-retailer takes more days up to 10-15 days.

(18) Most of the students face problems at the time of conducting online shopping. Most of them are faced with delayed delivery, cheap quality, and product damage problems.

(19) Majority of respondents are greatly concerned about the loss of privacy, theft of identity, risk of payment tools, and risk of not getting what they actually paid for.

(20) Delivery time, security, description of goods, and privacy of information are the most important factors to the respondents towards purchasing from online shops.
(21) Most of the students are satisfied with conducting online shopping.

(22) Most of the respondents think- Online shopping will replace physical shopping very soon.

(23) Students from BRI countries are quite familiar and responsive to the online shopping trend.

\section{RECOMMENDATIONS}

After analyzing data and findings, some recommendations can be specified-

- It is needed to provide a true description of each product and satisfying the customers by fulfilling promises.

- $\quad$ It is needed to decorate E-commerce apps and websites to attract more customer-friendly to online shopping. The design of the website should be clearer to make the purchase process smooth. Merchants should focus on functions such as search engines and categorize items to help customers' save time.

- Online shop owners are needed to create more language options for customers to choose the type of language they used to communicate better on the site.

- E-retailer should send the product to the customer's door at certain \& quickest time.

E-retailer should stay connected with the customer after selling products.

The price of the same product is different on different websites. E-retailers should take care of this so that consumers do not panic.

- E-retailer, E-commerce platforms should give the highest priority towards the protection of loss of privacy, identity theft, risk of payment tools, and delivering products that customers paid for.

Payment methods should be more secured and easier.

- E-retailer should take care of transportation and delivery system so that product may not damage and lost.

- E-retailer should develop the refund system more smoothly and quickest.

Should create innovative promotion and special focus to students as well as youth groups as they are the main driving force of E-platforms.

- It is needed for more advertisement and softness to shift customers from physical to online shopping.

- Online shops may take special promotional offers and activities for the youth group and students.

- Cross-border online shopping can be persuaded among China and Belt \& Road (BRI) countries. It can open a new trend to e-business, e-commerce as well as online shopping.

\section{CONCLUSION}

This study focuses specifically on university students from Belt and Road countries and analyzes their shopping behaviors, motivations, and barriers to online shopping. In particular, there are several factors such as privacy, firm reputation, perceived value, and trust have been found as the most influencing factors to purchase decision. This study 
found a significant positive relationship between price, product variety, product information, convenience, short delivery period, and payment security. This study suggests the online shop owners and the potential online shop owners, hence, some of the best means needed to improve in their customer services.

Through the findings of this research, online retailers could better realize online consumers' especially youth groups' expectations and the influencing factors of consumers' satisfaction. By understanding the key drivers that could impact online shopping attitudes, online retailers would be able to formulate and implement their E-business strategy efficiently and effectively and gain stronger competitive advantages. This study also suggests that online vendors should pay more attention to apply the marketing mix with high product quality, lower price, discount, free delivery, or gift to build, enhance and maintain their good reputation. Hosting companies such as Taobao, Jingdong, etc could set up their business strategy to meet both customer and retailer requirements. The hosting company may utilize high information technology strategy, big data to improve the functionalities of the online shopping platforms. It will assist online vendors in organizing the marketing mix of the promotional activities, enhance the reputation mechanism, and finally achieve both seller and consumer satisfaction.

E-revolution has been started in every sector already. The general business form is being transformed to E-business form with an unlimited speed. Online shopping is replacing physical shopping gradually. It is also changing international business mode. Now-a-days, cross-border ecommerce is the most discussing business subject in economic forums. Moreover, China's Belt \& Road Initiative (BRI) is started a new polarization in international business. This study will support understanding the consumer behavior of BRI countries. This study can also show paths to initiate cross border online shopping among Belt and Road countries.

Therefore, this study can provide implications to people who want to sell things in online domestically as we as world-wide. This study will definitely be useful to many merchants and businesses in the future.

\section{APPENDIX}

Questionnaire Online Link-

https://forms.office.com/Pages/ResponsePage.aspx?id=DQS IkWdsW0yxEjajBLZtrQAAAAAAAAAAAAO_SY9i1NU MU5GOUdaUUdTTjFFQVEwUVIGVFEzNUNIOC4u.

\section{ACKNOWLEDGMENT}

Gratitude to Professor Ms. Cheng, supervisor of the Ecommerce Course, for her valued guidance, availability, and technical advice. Indebted to all lecturers who taught me in the Bachelor and the Master programs, therefore enriching my research with knowledge. Thankful to the students of Capital Normal University (首都师范大学); who were my respondents, deserve my appreciation for their support during my survey study. Special gratefulness to classmates for giving encouragement and valuable suggestions for the betterment of the research.

\section{REFERENCES}

[1] Aghdaie, S. F., Piraman, A., \& Fathi, S. (2011). An analysis of factors affecting the consumer's attitude of trust and their impact on internet purchasing behaviour. International Journal of Business and Social Science, 2(23), 147-158.

[2] Ajzen, Icek, and Martin Fishbein. "Attitudes and the AttitudeBehavior Relation: Reasoned and Automatic Processes." European Review of Social Psychology, vol. 11, no. 1, Jan. 2000, pp. 1-33, doi:10.1080/14792779943000116.

[3] Anesbury, Z., Nenycz-Thiel, M., Dawes, J., \& Kennedy, R. (2016) How do shoppers behave online? An observational study of online grocery shopping. Journal of Consumer Behaviour. https://doi.org/10.1002/cb.1566.

[4] B. Hernandez, J. Jimenez, M.J. Martin. The impact of self-efficacy, ease of use and usefulness on e purchasing: an analysis of experienced e-shoppers. Interacting with Computers, 21 (2011), pp. 146-156.

[5] Cheng, H. and Fu, T. (2018). The Determinants of Online Shopping Behavior. [online] IEEE Xplore. Available-at: https://ieeexplore.iee.org/document/8494098 [Accessed 24 Nov. 2020].

[6] Clemes, M.D., Gan, C. and Zhang, J. (2014). An empirical analysis of online shopping adoption in Beijing, China. Journal of Retailing and Consumer Services, [online] 21(3), pp.364-375. Available at: https://ideas.repec.org/a/eee/joreco/v21y2014i3p364-375.html [Accessed 23 Nov. 2020].

[7] Constantinides, E. (2002), The 4S Web-marketing mix model, ecommerce research and applications, Elsevier Science, Vol. 1 No. 1, pp. 57-76.

[8] Daxue Consulting. "Payment Methods in China: How China Became a Mobile-First Nation | Daxue Consulting." Daxueconsulting.com,10, May,2019, daxueconsulting.com/payment-methods-in-china/.

[9] Delafrooz, N., Paim, L., Haron, S., Sidin, S. and Khatibi, A. (2009) Factors affecting students' attitude toward online shopping. African Journal of Business Management, [online] 3(5), pp.200209.Available-at: https://academicjournals.org/journal/AJBM/articlefull-text-pdf/9C92C4B16304.pdf [Accessed 24 Nov. 2020].

[10] Dennis, C., Morgan, A., Wright, L. T., \& Jayawardhena, C. (2010) The influences of social e-shopping in enhancing young women's online shopping behaviour. Journal of Customer Behaviour. https://doi.org/10.1362/147539210x511353.

[11] Diallo, M. F., Chandon, J.-L., Cliquet, G., \& Philippe, J. (2013). Factors influencing consumer behaviour towards store brands: Evidence from the French market. International Journal of Retail \&Distribution-Management,41(6),422-441. doi:10.1108/09590551311330816.

[12] Education on the Belt and Road The British Chamber of Commerce in China. (2019). [online] Available at: https://www.britishchamber.cn/wpcontent/uploads/2019/02/Education -on-the-Belt-and-Road-Final-0219.pdf.

[13] Elliot, S. and Fowell, S. (2000), Expectations versus reality: A snapshot of consumer experiences with Internet retailing, International Journal of Information Management, 20(5), 323-336.

[14] Enrique, B. A., Carla, R. M., Joaquin, A. M., \& Silvia, S. B. (2008). Influence of online shopping information dependency and innovativeness on internet shopping adoption. Online Information, Review-32(5),648-667. doi:10.1108/14684520810914025.

[15] Glass, G. V., \& Hopkins, K. D. (1984). Statistical methods in education and psychology (2nd ed.). Englewood Cliffs, NJ: PrenticeHall, pp. 341-349.

[16] Gong, W., Stump, R. L., \& Maddox, L. M. (2013). Factors influencing consumers' online shopping in China. Journal of Asia Business Studies, 7(3), 214-230. doi:10.1108/JABS-02-2013-0006.

[17] Hernández, Blanca, et al. "Customer Behavior in Electronic Commerce: The Moderating Effect of e-Purchasing Experience.' Journal of Business Research, vol. 63, no. 9-10, Sept. 2010, pp. 964 971, 10.1016/j.jbusres.2009.01.019. Accessed 30 Nov. 2020.

[18] https://eng.cnu.edu.cn/about/general/index.htm.

[19] https://forms.office.com/Pages/ResponsePage.aspx?id=DQSIkWdsW 0yxEjajBLZtrQAAAAAAAAAAAAO_SY9i1NUMU5GOUdaUUd TTjFFQVEwUVIGVFEzNUNIOC4u.

[20] Hosen, M. S. (2020). O2O Business Model of Meituan in China Global Disclosure of Economics and Business,9(1),49-66. https://doi.org/10.18034/gdeb.v9i1.508. 
[21] Jacoby, J., et al. "CONSUMER BEHAVIOR: A Quadrennium." Annual Review of Psychology, vol. 49, no. 1, Feb. 1998, pp. 319344, 10.1146/annurev.psych.49.1.319. Accessed 27 Oct. 2020.

[22] Jiang, J. C., Chen, C. A., \& Wang, C. C. (2008). Knowledge and trust in e-consumers' online shopping behavior. International symposium on electronic commerce and security, Guangzhou-China. IEEE Computer Society (pp. 652-656).

[23] Karimi, S., Papamichail, K. N., \& Holland, C. P. (2015). The effect of prior knowledge and decision-making style on the online purchase decision-making process: A typology of consumer shoppingbehaviour.-Decision-Support-Systems. https://doi.org/10.1016/j.dss.2015.06.004.

[24] Katawetawaraks, C., \& Dan Wang, C. L. (2011). Online shopper behavior: Influences of online shopping decision. Asian Journal of Business Research, 1(2), 1-9. doi:10.14707/ajbr.112.

[25] Lai, E., \& Wang, Z. (2012). An empirical research on factors affecting customer purchasing 2012 IEEE International Conference on Computer Science and Automation Engineering, Beijing-China.1583-586.

[26] "Impact of E-Commerce and E-Business on Retail Industry of Singapore-Research-Proposal-1."-Studentshare, studentshare.org/ecommerce/1748114-e-business-and-e-commerce.

[27] Melnik. M. I. and Aim, J., (2002), Does a seller's reputation matter? Evidence from eBay auctions. Journal of Industrial Economics 50;337-49.

[28] Michael A. Peters (2020) China's belt and road initiative: Reshaping global higher education, Educational Philosophy and Theory, 52:6, 586-592, DOI: 10.1080/00131857.2019.1615174.

[29] Peters, Michael A. "China's Belt and Road Initiative: Reshaping Global Higher Education.” Educational Philosophy and Theory, 19 May 2019, pp. 1-7, 10.1080/00131857.2019.1615174. Accessed 28 Oct. 2020

[30] Posselt, T. and Gerstner, E. (2005), Pre-sale vs. post-sale esatisfaction: impact on repurchase intention and overall satisfaction, Journal of Interactive Marketing, Vol. 19 No. 9, pp. 35-47.

[31] Sparks, R.E and Legault, R.D. (1993), A definition of quality for total customer satisfaction: the bridge between manufacturer and customer, Sam advanced management journal.

[32] "The Alibaba Phenomenon." The Economist, 23 Mar. 2013, www.economist.com/leaders/2013/03/23/the-alibaba-phenomenon.

[33] Vaidya, D.A. and Vaidya, A. (2017). ONLINE SHOPPING TRENDS AMONG COLLEGE STUDENTS. SMART MOVES JOURNAL IJELLH, [online] 5(8), pp.16-16. Available at: https://ijellh.com/OJS/index.php/OJS/article/view/2203 [Accessed 24 Nov. 2020].

[34] WANG, C.N. (n.d.). Countries of the Belt and Road Initiative (BRI) Green Belt and Road Initiative Center. [online] Available at: https://green-bri.org/countries-of-the-belt-and-road-initiative-bri [Accessed 29 Nov. 2020].

[35] Wu, L., Cai, Y. and Liu, D. (2011). Online shopping among Chinese consumers: an exploratory investigation of demographics and value orientation. International Journal of Consumer Studies, 35(4), pp.458-469.

[36] Yamamoto, C., Nishiyama, H. and Mano, S. (2016). E-commerce Environment Analysis in Chinese Market Based on Case Analysis of Amazon China 35142339-1 LI JIAMIN MANAGEMENT OF EXPERIENTIAL VALUES. [online] Available at: https://core.ac.uk/download/pdf/144468915.pdf [Accessed 24 Nov. 2020].

[37] Zongzheng (2018). Statistical report on international students in China for 2018 - Ministry of Education of the People's Republic of China. [online] Moe.gov.cn. Available at: http://en.moe.gov.cn/documents/reports/201904/t20190418_378692.h tml [Accessed 1 Dec. 2020].

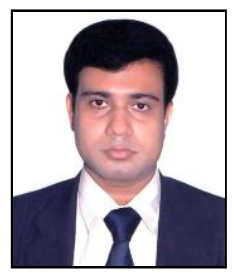

Mr. Md Shohidul Islam received a double Master's degree in International Business (MIB) and Business Administration (MBA) from Capital Normal University, China 首都师范大学 and Daffodil International University, Bangladesh, in 2021 and 2013, respectively. He obtained his Bachelor's degree in Business Administration from Asian University of Bangladesh in 2010. He attained PGDHRM from Bangladesh Institute of Management in 2012. In addition to his academic background, Mr. Islam worked in several multinational companies as Business Development Officer and Senior Administrative Officer.

His research interests cover various aspects of Business Model and Methodology Development, especially International Business, and Human Resources Development. He conducted a comprehensive Thesis project on Cross-border E-commerce under supervision by Ms. Lin Kong, Professor, College of Management, Capital Normal University, Beijing. Mr. Islam's research interest is in traits of International Trade \& Business, Crossborder E-commerce, Business potentials under China's Belt \& Road Initiative (BRI), and Regional Comprehensive Economic Partnership (RCEP); Digital Transformation of Business, Prospective of Big-Data, and Fin-tech. 